\title{
Colorectal cancer screening: a global overview of existing programmes
}

\author{
Eline H Schreuders, ${ }^{1}$ Arlinda Ruco, ${ }^{2}$ Linda Rabeneck, ${ }^{3,4,5,6,7}$ Robert E Schoen, ${ }^{8}$ \\ Joseph J Y Sung, ${ }^{9}$ Graeme P Young, $^{10}$ Ernst J Kuipers ${ }^{1}$
}

For numbered affiliations see end of article.

\section{Correspondence to}

Eline H Schreuders,

Department of

Gastroenterology and Hepatology, Erasmus MC, University Medical Centre, PO Box 2040, Rotterdam 3000 CA, The Netherlands; e.schreuders@erasmusmc.nl

Received 24 December 2014 Revised 12 May 2015 Accepted 13 May 2015 Published Online First 3 June 2015
CrossMark

To cite: Schreuders EH, Ruco A, Rabeneck $L$, et al. Gut 2015;64:1637-1649.

\section{ABSTRACT}

Colorectal cancer (CRC) ranks third among the most commonly diagnosed cancers worldwide, with wide geographical variation in incidence and mortality across the world. Despite proof that screening can decrease CRC incidence and mortality, CRC screening is only offered to a small proportion of the target population worldwide. Throughout the world there are widespread differences in CRC screening implementation status and strategy. Differences can be attributed to geographical variation in CRC incidence, economic resources, healthcare structure and infrastructure to support screening such as the ability to identify the target population at risk and cancer registry availability. This review highlights issues to consider when implementing a CRC screening programme and gives a worldwide overview of CRC burden and the current status of screening programmes, with focus on international differences.

\section{BACKGROUND}

Worldwide colorectal cancer (CRC) is the third most common cancer in men (746000 cases, $10.0 \%$ of the total) and the second in women (614 000 cases, $9.2 \%$ of the total). ${ }^{1}$ There is however wide geographical variation in CRC incidence and mortality, with very similar patterns in men and women. The age-standardised incidence rates (ASRi) vary 10 -fold in both sexes worldwide. When comparing world regions as classified by the United Nations, the highest estimated rates occur in the Australia/New Zealand region (ASRi 44.8 per 100000 and 32.2 per 100000 in men and women, respectively), and the lowest in western Africa (4.5 per 100000 and 3.8 per 100000 ). Almost $55 \%$ of CRC cases occur in more developed regions. ${ }^{1}$ However, in many developing countries (including some parts of Africa), there is the possibility of under-reporting because cancer registries are lacking or have incomplete coverage. Large disparities exist between high-income and lowincome countries in the proportion of their populations covered by cancer registries. ${ }^{2}$

The lifetime risk of developing CRC in many regions is around 5\%. Approximately $45 \%$ of persons diagnosed with CRC die as a result of the disease, despite treatment. ${ }^{3}$ Treatment modalities have largely improved over the past decade. Treatment has modestly improved disease outcome and extended survival in patients with advanced and metastatic disease. But, these advancements have been accompanied by markedly increased treatment costs. As a result, modelling studies have
Key messages

A successful screening programme for a major disease like colorectal cancer (CRC) requires comprehensive collaboration among multiple parties for an optimal effect in terms of gain in life-years, quality of life and cost efficiency.

- Despite well developed CRC screening guidelines, implementation of screening is markedly different among countries and regions in the world.

- In addition to CRC incidence, the impact of the disease relative to other health problems and the capacity to treat should be taken into account when developing a CRC screening strategy.

- The discrepancy between CRC incidence and the offer of organised or opportunistic screening remains an ongoing concern.

- Screening measures and quality indicators of screening should be reported, allowing national evaluation and international comparison to improve CRC screening quality.

shown that various screening strategies are costsaving. ${ }^{4}$ Most CRCs develop from a preclinical precursor, the adenoma. The progression from early adenoma to invasive cancer takes years. ${ }^{5} 6$ The high incidence, long preclinical phase, recognisable and treatable precursor, the high cost of treatment, and the correlation of mortality with disease stage make CRC highly suitable for population screening. ${ }^{7-9}$ This has been confirmed by randomised controlled trials (RCTs) that have formed the basis for international guidelines recommending CRC screening. ${ }^{10-13}$ Despite these recommendations, screening is currently only offered to a small proportion of the target population.

The goal of this review is to address various aspects to consider for implementing a successful screening programme and to give an overview of screening programmes worldwide, with a focus on international differences.

\section{METHODS}

For this review, national and international guidelines on CRC screening were evaluated. We collected information on CRC screening programme characteristics from guidelines, through national governmental websites and international contact persons including public health researchers, 
Table 1 Test performance per screening test in asymptomatic, average-risk adults

\begin{tabular}{|c|c|c|c|c|c|}
\hline & gFOBT & FIT & FS & СTC & Colonoscopy \\
\hline Sensitivity (\%) for detecting advanced neoplasia & 9 to $24^{43-48}$ & 32 to $53^{43444749}$ & 90 to $92^{* 50}$ & $88^{35}$ to $97^{43}$ & 88 to $98^{51}$ \\
\hline Sensitivity (\%) for detecting CRC & 13 to $50^{44-46}$ & $79^{52}$ & 90 to $92 * 50$ & $100 t^{53}$ & 92 to $99^{50}$ \\
\hline Reduction in CRC incidence (\%) intention-to-screen & Noł $\ddagger^{19} 54$ & Unknown & $18^{54}$ & Unknown & $69 \S^{55}$ \\
\hline Reduction in CRC mortality (\%) intention-to-screen & 14 to $16^{19}$ & $22 \rrbracket^{25}$ & $28^{54}$ & Unknown & $68 \S^{55}$ \\
\hline \multicolumn{6}{|c|}{$\begin{array}{l}\text { *Sensitivity is given for the distal colon. } \\
\text { †No CRCs were missed by CTC in six screening trials. } \\
\text { ¥No reduction in incidence was found in three of four RCTs included in meta-analysis. } \\
\text { § Meta-analysis of observational studies, more results expected. } \\
\text { ๆी Ecological study. } \\
\text { CRC, colorectal cancer; CTC, CT colonography; FIT, faecal immunochemical test for haemoglobin; FS, flexible sigmoidoscopy; gFOBT, guaiac faecal occult blood test; RCT, randomised } \\
\text { controlled trial. }\end{array}$} \\
\hline
\end{tabular}

those responsible for the development and implementation of screening programmes and participants of the Colorectal Cancer Screening Committee of the World Endoscopy Organisation. ${ }^{14}$ A literature search in PUBMED and The Cochrane Central Register of Controlled Trials was performed using the following keywords: CRC screening, guidelines, Europe/ America/ Canada/ Asia/ Australia/ New Zealand, RCTs, colonoscopy, guaiac faecal occult blood test (gFOBT), faecal immunochemical test for haemoglobin (FIT), flexible sigmoidoscopy (FS), CT colonography (CTC), DNA-marker and video capsule endoscopy. To evaluate and compare screening programmes, we used the universally applicable CRC screening indicators established by the International Colorectal Cancer Screening Network based on the criteria of the International Agency for Research on Cancer (IARC). ${ }^{15} 16$ To report screening indicators regarding FIT screening, the Faecal Immunochemical TesTs for haemoglobin Evaluation Reporting guidelines were followed. ${ }^{17}$ We used the recommended reporting units of microgram haemoglobin per gram faeces ( $\mu \mathrm{g} \mathrm{Hb} / \mathrm{g}$ ) rather than nanogram haemoglobin per millilitre buffer (ng $\mathrm{Hb} / \mathrm{mL}$ ) to ensure comparability of results. ${ }^{18}$ The term 'average risk population' used in this review refers to an asymptomatic population who is at average risk for CRC. The age range of this population is influenced by national guidelines and varies per study but is mainly over age 50 years and constantly over age 40 years. For the overview of current status of screening programmes, at least the top 10 countries with highest age-ASRi for each world continent were included.

\section{SCREENING METHODS}

Detection and removal of cancer precursors can reduce CRC incidence and mortality. Early detection of CRC allows less invasive treatment, with lower morbidity, mortality and treatment cost. The implementation of a CRC screening programme requires that strategic decisions be addressed. One is the selection of a screening modality, which can be a non-invasive test or an invasive test.

\section{Non-invasive stool tests}

Non-invasive stool tests include gFOBTs and FITs. These inexpensive tests detect microscopic amounts of blood by targeting either haem (gFOBTs) or human globin (FITs). A meta-analysis of four RCTs concluded that annual or biennial gFOBT screening had no effect on CRC incidence (in three out of the four studies included in the analysis) but led to an average $16 \%$ reduction in CRC-related mortality. ${ }^{19}$ The impact of the gFOBT is limited by the poor to moderate sensitivity for advanced adenomas and cancer (table 1). ${ }^{20}$ For this reason, gFOBTs are typically used on multiple bowel movements per screening, and are implemented in repeated screening rounds. In contrast, FITs have a higher sensitivity for adenoma and cancer even with a single sample per screening round (table 1). Moreover, unlike gFOBTs, FITs are specific for human globin and do not require dietary restriction. Thus, FIT screening is generally associated with higher participation and higher detection rates of adenomas and CRCs compared with gFOBT screening. ${ }^{21} 22$ Furthermore, quantitative FITs offer the opportunity to provide tailored screening by adjusting the positivity cut-off level. This can be used to adjust screening to available resources and colonoscopy capacity. ${ }^{4}{ }^{23}$ A low cut-off increases the detection of advanced neoplasia, but lowers the positive predictive value and specificity thus demanding more colonoscopy resources. ${ }^{24} \mathrm{No}$ RCT has reported the impact of FIT screening on CRC incidence and mortality. A recent ecological study compared regions in Italy with and without population FIT screening. CRC-specific mortality was $22 \%$ lower in areas with a FIT screening programme compared with areas without a screening programme. ${ }^{25}$ The higher uptake and sensitivity of FIT supports the assumption that biennial FIT screening at a low cut-off will have a larger impact than gFOBT on CRC incidence and mortality. Modelling studies suggest that the impact can approach that of colonoscopy if the adherence to multiple rounds is high. ${ }^{26}$

\section{Invasive imaging techniques}

Four RCTs showed that a single round of FS screening is associated with a reduction in CRC incidence of $18-23 \%$ and CRC mortality of $22-31 \% .^{27-30}$ Similar RCTs evaluating colonoscopy are underway, namely the NordICC (NCT00883792), COLONPREV (NCT00906997), SCREESCO (NCT02078804) and the CONFIRM (NCT01239082) studies. $^{31} 32$ CRC incidence and mortality results from these RCTs are expected between 2025 and 2034.

Colonoscopy is generally considered the gold standard for the detection of colorectal neoplasia. In prospective cohort studies, colonoscopy has been associated with long-term (20-30 years) reduction in CRC mortality. ${ }^{33} 34$ As such, some screening programmes use colonoscopy as the primary screening tool. Other programmes prefer a two-step approach, using colonoscopy only for diagnostic clarification in those with a positive first-line less invasive screening test. The latter approach has, for some countries, the advantages of higher screening uptake and lesser demand on limited colonoscopy resources.

Precursor lesions and cancer can be visualised by CTC, also called virtual colonoscopy. In an average risk population, the per-patient sensitivity of CTC for advanced neoplasia $\geq 10 \mathrm{~mm}$ was $88 \% .^{35}$ However, this sensitivity decreases for the detection of polyps $<10 \mathrm{~mm} .^{36} 37$ Compared with stool tests, imaging tests such as CTC are more invasive (making them more burdensome) and costlier. 
Colonoscopy is considered the primary diagnostic method to evaluate a positive less invasive screening test, whether that test is based on evaluating stool, serum (blood) or colorectal imaging. The demand and capacity for colonoscopy must be taken into account when a country chooses a screening modality.

\section{New screening modalities}

Other screening methods have become available for CRC screening. Newer non-invasive tests include DNA, RNA and protein biomarker stool and blood tests. Detection of circulating methylated SEPT9 DNA in blood yielded a CRC sensitivity of $48 \%$, which is at the lower end of the gFOBT range $(37-79 \%) .{ }^{38} 39$ Sensitivity for the detection of advanced adenomas was very low (11\%). ${ }^{39}$ Biomarker stool tests are based on the principle that colorectal neoplasms shed surface cells in the stool. DNA from these cells can be isolated and tested for the presence of mutations and epigenetic changes acquired during carcinogenesis. Stool DNA testing has improved over the last decade. A recent study incorporating FIT with DNA markers, reported a $92.3 \%$ sensitivity for CRC and $42.4 \%$ for advanced adenomas, which was significantly higher than FIT at a cut-off of $20 \mu \mathrm{g} \mathrm{Hb} / \mathrm{g}$ faeces $(100 \mathrm{ng} / \mathrm{mL}$ ) (sensitivity for cancer $72 \%$, for advanced adenoma $23 \%){ }^{40}$ One cautionary note about this study is the difference in positivity rates between the DNA and FIT that were used. Both non-invasive tests are meant to select subjects at a higher risk of neoplasia so they can undergo colonoscopy. In other words, a non-invasive test aims to enrich the population undergoing colonoscopy and relieves those at low risk of neoplasia of the burden and risk of colonoscopy. In this particular study, the investigators used a relatively high FIT cut-off and a more 'liberal' DNA cut-off. As a result, the number of persons referred for colonoscopy was more than twice as high after stool DNA testing than after FIT. In further comparisons between non-invasive tests, there is a need to set the cut-off of each test at such a level that both tests yield a similar positivity rate, since this determines colonoscopy demand and thus largely influences the burden and costs of a screening programme.

Newer imaging tests include colon capsule endoscopy (CCE) and magnetic resonance colonography (MRC). CCE is a procedure that uses an ingestible capsule with a camera at each end to produce images of the mucosa during intestinal transit. The average sensitivity of second generation CCE (CCE-2) devices for significant findings ( $\geq 6 \mathrm{~mm}$ size, or $\geq$ three polyps irrespective of size) is $86 \%$. When used as a triage test after a positive FIT to determine who should proceed to colonoscopy, CCE has the potential to reduce the number of colonoscopies performed by $71 \%$. In case of an incomplete colonoscopy, the diagnostic yield of CCE has been reported to be superior to that of CTC for polyps $\geq 6 \mathrm{~mm}$ as well as $\geq 10 \mathrm{~mm}$ with colonoscopy as the gold standard. ${ }^{41}$ An MRC study performed in 286 asymptomatic individuals reported a sensitivity of $78.4 \%$ for adenomas $>6 \mathrm{~mm} .{ }^{42}$ The impact of these new screening modalities on screening uptake and CRC incidence and mortality requires further study.

The efficacy of different screening methods in terms of impact on CRC incidence and mortality is not known. Table 1 outlines the performance of different screening tests in an average risk population. For the given rates of reduction in CRC incidence and mortality, results of a single round as well as multiple rounds were included in this table. Advanced neoplasia is defined as an adenoma $\geq 10 \mathrm{~mm}$, or $\geq 25 \%$ villous component, or with high-grade dysplasia or CRC. More recently, attention has also been drawn to the relevance of larger or dysplastic serrated polyps as potential CRC precursors. The accuracy of individual screening methods in detecting these lesions is under study.

\section{ORGANISED AND OPPORTUNISTIC SCREENING}

An organised screening programme involves a systematic process of inviting a target population to participate in screening and ensuring follow-up of those with a positive screen. An organised programme should measure and report on the quality of each step in the screening process. The IARC outlines the following elements for organised screening programmes:

- An explicit policy with specified age categories, screening method and screening interval

- A defined target population

- A management team responsible for implementation

- A healthcare team for decisions, care and follow-up of patients with positive screening tests

- A quality assurance structure for every step in the process

- A process for monitoring, evaluating and identifying cancer occurrence in the population. ${ }^{16}$

In organised screening, substantial information technology infrastructure is required to support the programme including systems for invitations, recalls, reminders, tracking of screening results, ensuring follow-up and tracking of clinical outcomes such as cancer incidence, mortality and stage. ${ }^{56}$ For tracking of screening results, a set of universally applicable CRC screening measures and indicators have been established. ${ }^{15}$ A cancer registry is critical and can be linked to all other relevant databases including laboratories and endoscopic centres. ${ }^{56}$ In contrast, opportunistic screening is delivered outside of an organised screening programme on an ad hoc basis usually through fee-for-service reimbursement of physicians. Since organised screening focuses on quality assurance, it provides greater protection against the possible harms of screening including overscreening and underscreening, poor quality, inappropriate use of resources, complications arising from screening and poor follow-up of those with a positive screen. ${ }^{57}$

The approach to screening in the USA is largely opportunistic. The contributions and quality initiatives from many national bodies has been crucial, including the US Preventive Services Task Force (USPSTF), an independent volunteer panel of national experts in prevention and evidence-based medicine that reviews evidence and makes recommendations to guide the choice of CRC screening tests. ${ }^{58}$ In addition, multiple professional associations have emphasised the importance of colonoscopy quality in the context of CRC screening. ${ }^{1159}$ Equity of access to screening in the USA remains uncertain, however. ${ }^{60}$

\section{Quality assurance}

In 2010, the IARC published the European Guidelines for Quality Assurance in Colorectal Cancer Screening and Diagnosis. ${ }^{12}$ These guidelines outline targets for key performance indicators for CRC screening including participation, follow-up and cancer detection rates. For example, the guidelines recommend that invitation coverage in the target population should be high (95\%) and that programmes should aim for participation rates of at least $65 \% .^{61}$

Given that at least 10 years are required to plan, pilot and implement a screening programme, the full impact of a nationwide screening programme on indicators such as CRC mortality rates requires long follow-up. ${ }^{62}$ Therefore, an intermediate measure may be used to evaluate programme performance, expressed as the number of persons with advanced 
Table 2 Performance of a first round screening programme per screening test, based on screening indicators.

\begin{tabular}{|c|c|c|c|c|c|}
\hline & gFOBT & FIT & FS* & CTC & Colonoscopy \\
\hline Participation rate $(\%)$ & $16-47$ & $17-77$ & $30-84$ & $18-34$ & $16-93$ \\
\hline Positivity rate† (\%) & $2.4-6.8$ & $1.1-13$ & $5.3-23$ & $8.6-9.0$ & $4.9-11$ \\
\hline Advanced neoplasia detection rateł $(\%)$ & $29-50$ & $16-43$ & $20-100$ & $54-71$ & 100 \\
\hline Detected advanced neoplasia per 1000 invited individuals§ & $2.1-6.3$ & $1.1-21$ & $23-39$ & $8.8-21$ & $14-73$ \\
\hline References & $21,22,63,64$ & $21,22,32,64-72$ & $21,68,73,74,75$ & 76,77 & $32,68,76-79$ \\
\hline
\end{tabular}

neoplasia detected per 1000 invited individuals during the screening interval. This measure takes multiple factors into consideration namely participation rate, positivity rate and the positive predictive value for the detection of advanced neoplasia. It is thus a balanced assessment of the overall performance of a screening programme. Table 2 outlines the number of people with advanced neoplasia identified per 1000 invited individuals in those programmes that have published their results. There is marked variation across screening tests and within a screening test type for all indicators. Wide ranges for the gFOBT/FIT-based results may be due to the use of more sensitive tests or more stringent criteria for defining test positivity.

\section{Cost-effectiveness}

Cost-effectiveness studies for CRC screening have concluded that screening is cost-effective compared with no screening. ${ }^{80-82}$ Microsimulation models can help to identify the most appropriate screening strategy given the available resources and budget constraints. The efficiency frontier will identify strategies that are the most effective in terms of life-years gained relative to the cost of the screening strategy.

Cost-effectiveness studies have shown that screening can also be cost-effective in countries with limited financial resources. ${ }^{83}$ However, access to and improvement in CRC treatment may be a higher priority than screening in these settings. Using resources to implement population-based screening in a region with no or very limited access to treatment would not be a costeffective measure. ${ }^{84} 85$

\section{CRC SCREENING PROGRAMMES WORLDWIDE}

Over the past two decades, the range of CRC screening modalities has expanded, and many population-based programmes have been implemented. Nevertheless, large geographical variations remain with respect to implementation of CRC screening (figure $1 \mathrm{~A}-\mathrm{C}$ ). As expected screening programmes have been more frequently implemented in Western countries with higher CRC incidence and more available resources. Table 3 shows an overview of screening methods used worldwide grouped into the six WHO regions.

A

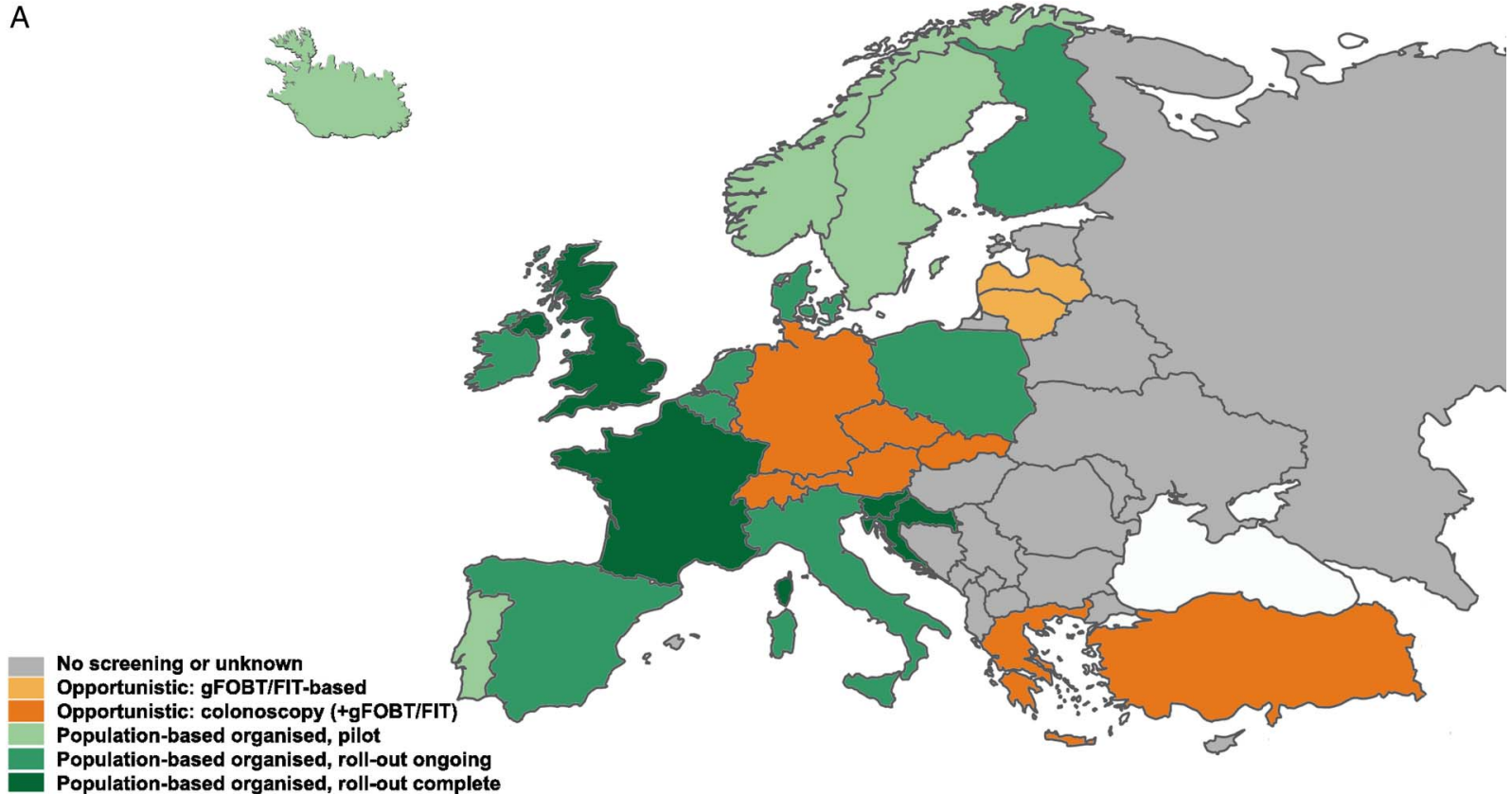

Figure 1 Overview of screening programmes 2014. Regional differences within one country are, except for North-America, not taken into account in these figures. (A) Overview of screening programmes in European region. (B) Overview of screening programmes in region of the Americas. (C) Overview of screening programmes in Western Pacific, South-East Asia and Eastern Mediterranean region. FIT, faecal immunochemical test for haemoglobin; gFOBT, guaiac faecal occult blood test. 


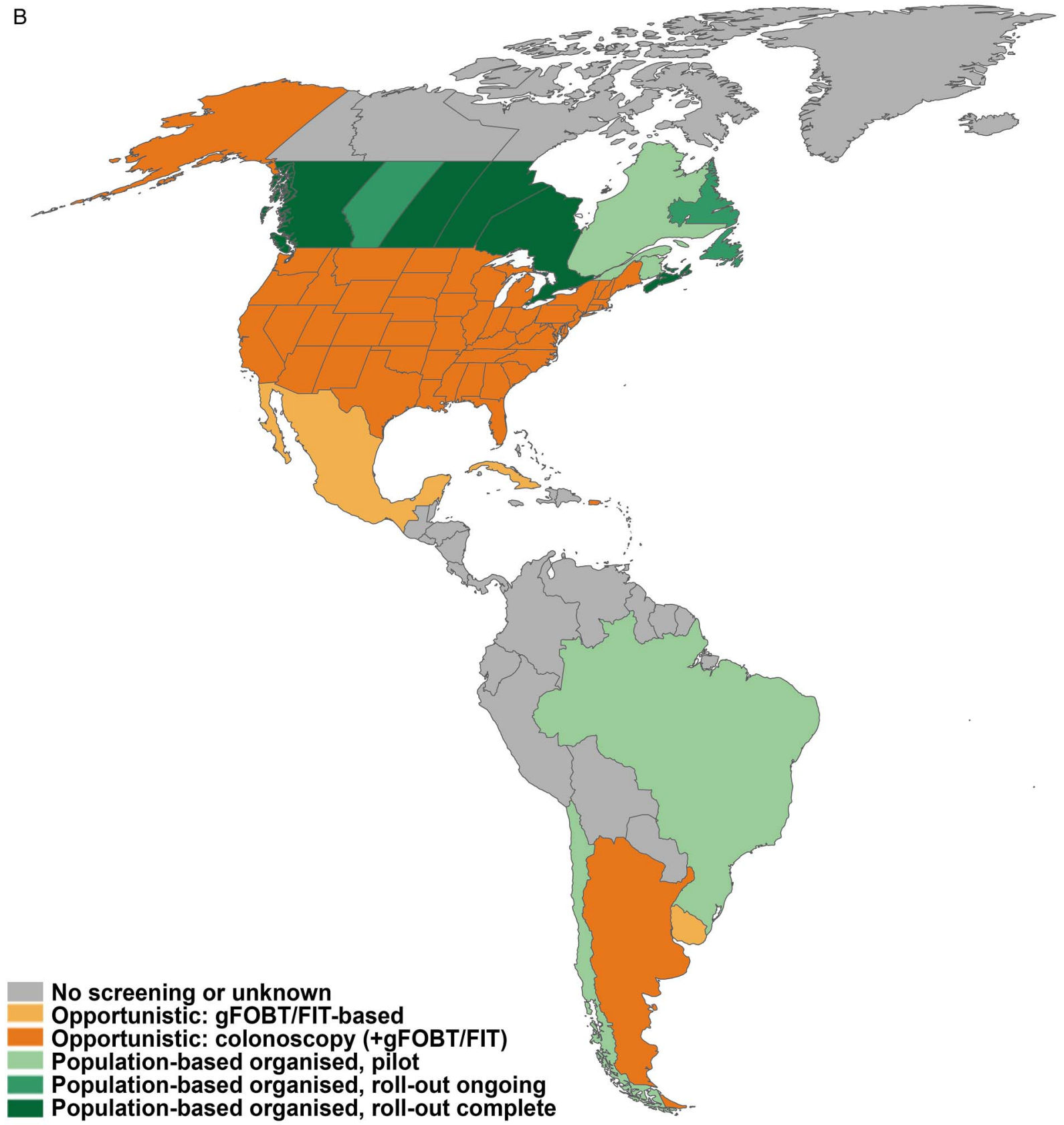

Figure 1 Continued

\section{European region}

Within Europe, the ASRi rates show a fivefold variation, with lowest rates for men and women in the Balkan countries of Bosnia Herzegovina (30 per 100000 and 19 per 100 000, respectively) and Albania (13 per 100000 and 11 per 100 000 , respectively). Highest incidence rates in men are found in Slovakia, Hungary and the Czech Republic, while highest incidence rates in women are found in Norway, Denmark and The Netherlands. ${ }^{1}$ Although CRC mortality rates follow a similar geographical pattern to incidence rates, CRC mortality is also high in some countries with relatively low incidence rates (Moldova, Russia, Montenegro, Poland and Lithuania). ${ }^{86}$ A low CRC incidence accompanied by a high CRC mortality can imply limited access to healthcare, and/or suboptimal CRC treatment. It is estimated that in 2015 around 490000 Europeans will be diagnosed with CRC and 240000 will die from the disease. ${ }^{1}$
There are large variations among national CRC screening practices in Europe especially since European guidelines for CRC first appeared in $2010 .^{12}$ Various screening programmes (pilot, opportunistic or organised) were already in place at that time. There are also considerable differences with respect to financial resources available for screening. The same pertains to colonoscopy capacity, with a more than threefold variation in endoscopy resources across European countries. Taken together, these factors have led to widespread variation. For details by country, see table 3 .

Most countries in Europe have implemented an organised screening programme. Nine countries have an opportunistic programme in place, and 16 countries either have or are beginning to implement organised screening (table 3). In 2015, 24 out of 28 European Union countries had established or were preparing a nationwide organised or opportunistic CRC screening programme. 


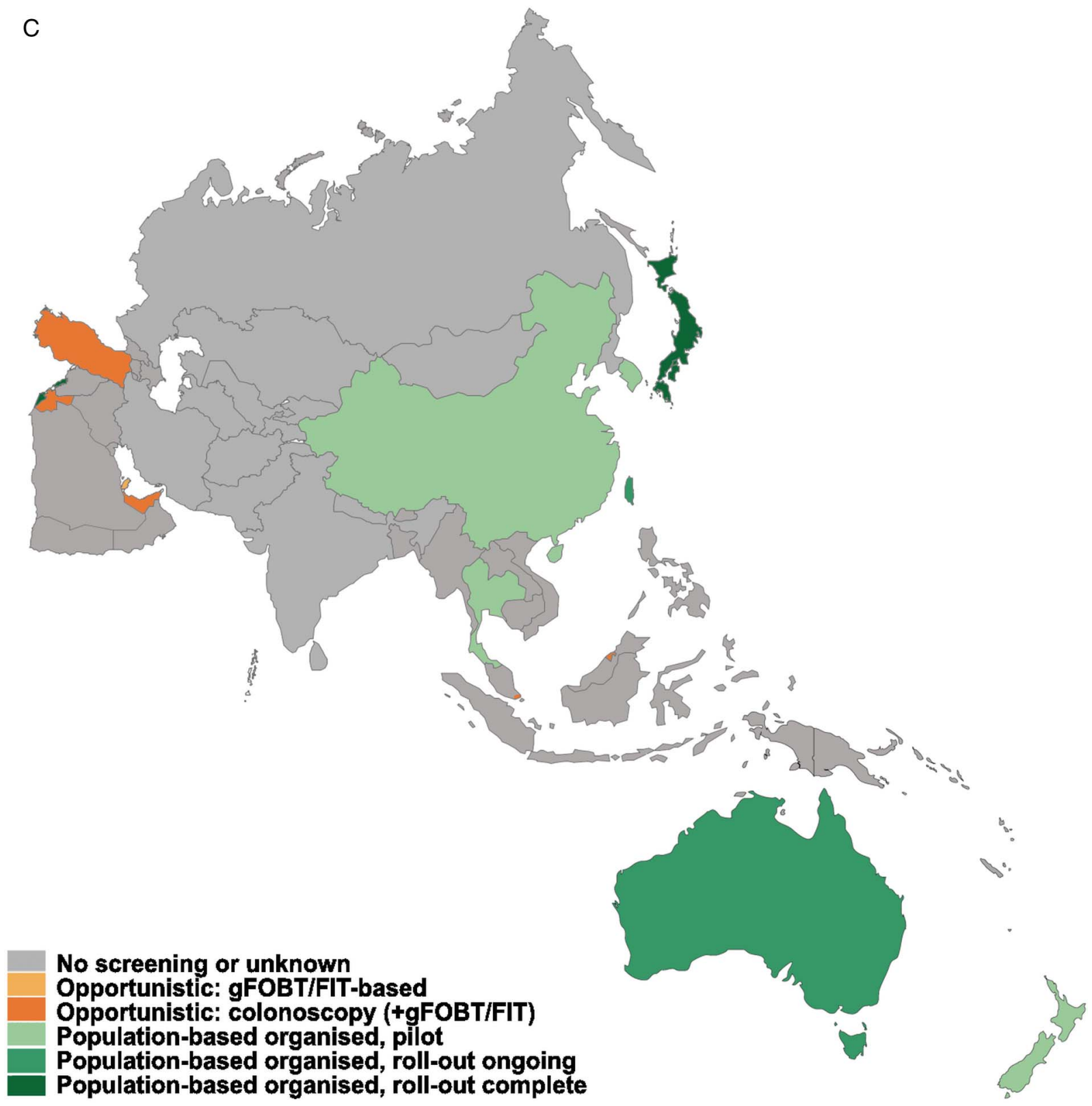

Figure 1 Continued.

For instance Finland, France, Slovenia and the UKhave completed rollout of their organised programmes. In Belgium, The Netherlands, Denmark, Ireland, Italy, Malta, Poland and Spain, rollout is ongoing. Norway, Portugal and Sweden are in the pilot phase.

Some countries have yet to implement a screening programme. For instance, the Greek Hellenic Society of Gastroenterology released guidelines for CRC screening in 2013. Despite previous low uptake and restricted resources, it recommended colonoscopy as the method of choice for CRC screening. Implementation of an organised programme is in a planning phase.

Slovakia has the highest CRC rates in Europe (world ASRi is 43 per 100000 and age-standardised mortality rate is 18 per $100000) .{ }^{1}$ However, the country does not have a CRC screening programme, despite the Ministry of Health publishing a list of departments performing screening colonoscopy. ${ }^{87}$ Further work is needed to move forward with a national screening programme. No population-based CRC screening programme is in place in Bulgaria, Albania, Bosnia and Herzegovina, Kosovo, Macedonia, Montenegro, Romania, Serbia or Russia. ${ }^{88} 89$

Most European countries with an organised programme screen by means of a non-invasive stool test, in which previously implemented gFOBT based programmes are switching to FIT, such as the UK since 2014 and France since 2015. FS is gradually being introduced in England. As of March 2015, about two-thirds of screening centres were beginning to offer this one-time-only test to 55 year-olds. Countries with an opportunistic programme are sometimes faced with low screening uptake. Such is the case in Austria and the Czech Republic, which has achieved coverage of approximately $25 \%$ of the target population. ${ }^{90} 91$ Organised programmes may also face uptake issues, such as in France and Croatia. In France participation rates were initially $34.3 \%$ in the first 2 years, with nearly three million people being screened. ${ }^{92}$ Active participation by general practitioners increased the participation up to $50 \%$ in some parts of the country. ${ }^{93}$ The participation rate in Croatia after 3 years of invitations of about a million people was only $19.9 \% .^{94}$ 
Table 3 Characteristics of screening programmes worldwide, presented alphabetically by country within regions defined by WHO (last updated May 2015)

\begin{tabular}{|c|c|c|c|c|c|c|c|c|c|c|}
\hline Country & ASRi & ASRm & Region(s) & $\begin{array}{l}\text { Programme } \\
\text { type }\end{array}$ & $\begin{array}{l}\text { Status of } \\
\text { organised } \\
\text { programme }\end{array}$ & $\begin{array}{l}\text { Type of } \\
\text { test }\end{array}$ & $\begin{array}{l}\text { Definition } \\
\text { positive test }\end{array}$ & $\begin{array}{l}\text { Starting } \\
\text { year }\end{array}$ & $\begin{array}{l}\text { Age range } \\
\text { (years) }\end{array}$ & $\begin{array}{l}\text { Screening } \\
\text { interval } \\
\text { (months) }\end{array}$ \\
\hline \multicolumn{11}{|l|}{ European region } \\
\hline \multirow[t]{2}{*}{ Austria } & 26 & 9. 9 & All & Opportunistic & & gFOBT & & 1980 & $40+$ & 12 \\
\hline & & & All & Opportunistic & & $\mathrm{OC}$ & & 2005 & $50+$ & $84-120$ \\
\hline \multirow[t]{3}{*}{ Belgium } & 36.7 & 11.8 & & & & & & & & \\
\hline & & & Flanders & Organised & Rollout ongoing & FIT & $15 \mu \mathrm{g} \mathrm{Hb} / \mathrm{g}$ & 2013 & $56-74$ & 24 \\
\hline & & & Wallonia and Brussels & Organised & Rollout complete & gFOBT & & 2009 & $50-74$ & 24 \\
\hline Bulgaria & 66.6 & 16 & & & & & & & & \\
\hline Croatia & 32.9 & 18.7 & All & Organised & Rollout complete & gFOBT & 1/12 slides & 2007 & $50-74$ & 24 \\
\hline Czech Republic & 39.9 & 15.4 & $\begin{array}{l}\text { All } \\
\text { All }\end{array}$ & $\begin{array}{l}\text { Opportunistic } \\
\text { Opportunistic }\end{array}$ & & $\begin{array}{l}\text { FIT } \\
\text { OC/FIT }\end{array}$ & & $\begin{array}{l}2000 \\
2010\end{array}$ & $\begin{array}{l}50-54 \\
55+\end{array}$ & $\begin{array}{l}12 \\
120 / 24\end{array}$ \\
\hline Denmark & 40.5 & 14.5 & All & Organised & Rollout ongoing & FIT & $20 \mu \mathrm{g} \mathrm{Hb} / \mathrm{g}$ & 2014 & $50-74$ & 24 \\
\hline Estonia & 27.2 & 12.3 & & & & & & & & \\
\hline Finland & 23.5 & 8.3 & All & Organised & Rollout ongoing & gFOBT & & 2009 & $60-69$ & 24 \\
\hline France & 30 & 10.2 & All & Organised & Rollout complete & FIT & $30 \mu \mathrm{g} \mathrm{Hb} / \mathrm{g}$ & 2009 & $50-74$ & 24 \\
\hline \multirow[t]{2}{*}{ Germany } & 30.9 & 10.4 & All & Opportunistic & & gFOBT & 1/6 slides & 1971 & $50-54$ & 12 \\
\hline & & & All & Opportunistic & & $\begin{array}{l}\text { OCl } \\
\text { gFOBT }\end{array}$ & & 2002 & $55+$ & $120 / 24$ \\
\hline Greece & 13.5 & 7.5 & All & Opportunistic & & $\mathrm{OC}$ & & & $50-80$ & \\
\hline Hungary & 42.3 & 20.8 & & & & & & & & \\
\hline Iceland & 28.4 & 7.4 & & Organised & $\begin{array}{l}\text { Pilot/planning } \\
\text { phase }\end{array}$ & & & & & \\
\hline $\begin{array}{l}\text { Ireland, republic } \\
\text { of }\end{array}$ & 34.9 & 12.2 & All & Organised & Rollout ongoing & FIT & $45 \mu \mathrm{g} \mathrm{Hb} / \mathrm{g}$ & 2012 & $55-74$ & \\
\hline Italy & 33.9 & 10.8 & $\begin{array}{l}\text { All } \\
\text { Piedmont/Veneto }\end{array}$ & $\begin{array}{l}\text { Organised } \\
\text { organised }\end{array}$ & $\begin{array}{l}\text { Rollout ongoing } \\
\text { pilot }\end{array}$ & $\begin{array}{l}\text { FIT } \\
\text { FS }\end{array}$ & $20 \mu \mathrm{g} \mathrm{Hb} / \mathrm{g}$ & 1982 & $\begin{array}{l}44-75 \\
58-60\end{array}$ & $\begin{array}{l}24 \\
\text { once }\end{array}$ \\
\hline Latvia & 23.7 & 12.9 & All & Opportunistic & & gFOBT & $1 / 9$ slides & 2005 & $50+$ & 12 \\
\hline Lithuania & 23.4 & 13.7 & Regions & Opportunistic & & FIT & & 2009 & $50-75$ & 24 \\
\hline Luxembourg & 31.5 & 11.2 & All & Opportunistic & & $\mathrm{gFOBT/OC}$ & & 2005 & $50+$ & \\
\hline Malta & 31.9 & 12.2 & All & Organised & Rollout ongoing & FIT & & 2012 & $60-64$ & 12 \\
\hline The Netherlands & 40.2 & 13.4 & All & Organised & Rollout ongoing & FIT & $47 \mu \mathrm{g} \mathrm{Hb} / \mathrm{g}$ & 2014 & $55-75$ & 24 \\
\hline Norway & 38.9 & 13 & Regions & Organised & Pilot & $\begin{array}{l}\text { OC/FS/ } \\
\text { FIT }\end{array}$ & & 2012 & $50-64$ & \\
\hline Poland & 27 & 14.5 & All & Organised & Rollout ongoing & $\mathrm{OC}$ & & 2000 & $50-66$ & 120 \\
\hline Portugal & 31.7 & 13.6 & Centre region & Organised & Pilot & gFOBT & & 2008 & & \\
\hline Romania & 26.4 & 13.4 & & & & & & & & \\
\hline Slovakia & 42.7 & 18 & All & Opportunistic & & $\mathrm{gFOBT/OC}$ & & & & \\
\hline Slovenia & 37 & 16.2 & All & Organised & Rollout complete & FIT & $\begin{array}{l}1 / 2 \text { samples at } \\
67 \mu \mathrm{g} \mathrm{Hb} / \mathrm{g}\end{array}$ & 2009 & $50-69$ & 24 \\
\hline Spain & 33.1 & 12.3 & Regions & Organised & Rollout ongoing & FIT & & 2000 & $60-69$ & 24 \\
\hline Sweden & 29.2 & 10.9 & Regions & Organised & Pilot & $\mathrm{gFOBT/FIT}$ & $10 C$ & & & \\
\hline Switzerland & 29.4 & 10.9 & & Opportunistic & & $\mathrm{gFOBT/OC}$ & & & $50+$ & \\
\hline Turkey & 16.6 & 10.0 & All & Opportunistic & & $\mathrm{FIT} / \mathrm{OC}$ & & 2009 & $50-74$ & $24 / 120$ \\
\hline \multirow[t]{5}{*}{ UK } & 30.2 & 10.7 & & & & & & & & \\
\hline & & & England & Organised & $\begin{array}{l}\text { Rollout complete } \\
\text { rollout ongoing } \\
\text { pilot }\end{array}$ & $\begin{array}{l}\text { gFOBT } \\
\text { FS } \\
\text { FIT }\end{array}$ & $\begin{array}{l}5 / 6 \text { slides }^{*} \\
20 \mu \mathrm{g} \mathrm{Hb} / \mathrm{g}\end{array}$ & $\begin{array}{l}2006 \\
2013 \\
2014\end{array}$ & $\begin{array}{l}60-74 \\
55+60-74\end{array}$ & $\begin{array}{l}24 \\
\text { once } \\
24\end{array}$ \\
\hline & & & Scotland & Organised & $\begin{array}{l}\text { Rollout complete } \\
\text { pilot }\end{array}$ & $\begin{array}{l}\text { gFOBT } \\
\text { FIT }\end{array}$ & $\begin{array}{l}5 / 6 \text { slidest } \\
80 \mu \mathrm{g} \mathrm{Hb} / \mathrm{g}\end{array}$ & $\begin{array}{l}2007 \\
2010\end{array}$ & $\begin{array}{l}50-74 \\
50-74\end{array}$ & $\begin{array}{l}24 \\
24\end{array}$ \\
\hline & & & Wales & Organised & Rollout complete & gFOBT & 5/6 slidest & 2008 & $60-74$ & 24 \\
\hline & & & Northern Ireland & Organised & Rollout complete & $\mathrm{gFOBT}$ & $5 / 6$ slides $t$ & 2010 & $60-74$ & 24 \\
\hline Ukraine & 23.4 & 13.7 & & Unknown & & & & & & \\
\hline \multicolumn{11}{|c|}{ Region of the Americas } \\
\hline Argentina & 23.8 & 13 & Urban areas & Organised & Pilot & $\mathrm{FIT} / \mathrm{OC}$ & & & $50-74$ & 12 \\
\hline Bahamas & 20.3 & 10.8 & & Opportunistic & & gFOBT/FIT & IOC & & & \\
\hline Barbados & 28.4 & 14.1 & & Opportunistic & & gFOBT/FIT & $10 C$ & & & \\
\hline Brazil & 15.8 & 8 & Regions/Sao Paulo & Organised & Pilot & FIT & & & & \\
\hline
\end{tabular}


Table 3 Continued

\begin{tabular}{|c|c|c|c|c|c|c|c|c|c|c|}
\hline Country & ASRi & ASRm & Region(s) & $\begin{array}{l}\text { Programme } \\
\text { type }\end{array}$ & $\begin{array}{l}\text { Status of } \\
\text { organised } \\
\text { programme }\end{array}$ & $\begin{array}{l}\text { Type of } \\
\text { test }\end{array}$ & $\begin{array}{l}\text { Definition } \\
\text { positive test }\end{array}$ & $\begin{array}{l}\text { Starting } \\
\text { year }\end{array}$ & $\begin{array}{l}\text { Age range } \\
\text { (years) }\end{array}$ & $\begin{array}{l}\text { Screening } \\
\text { interval } \\
\text { (months) }\end{array}$ \\
\hline \multirow[t]{14}{*}{ Canada } & 35.2 & 10.8 & & & & & & & & \\
\hline & & & Ontario & Organised & $\begin{array}{l}\text { Rollout complete } \\
\text { (switching to FIT) }\end{array}$ & gFOBT & 1/6 slides & 2008 & $50-74$ & 24 \\
\hline & & & British Columbia & Organised & Rollout complete & FIT & $\begin{array}{l}1 / 2 \text { samples at } \\
20 \mu \mathrm{g} \mathrm{Hb} / \mathrm{g}\end{array}$ & 2009 & $50-74$ & 24 \\
\hline & & & Alberta & Organised & Rollout ongoing & FIT & $15 \mu \mathrm{g} \mathrm{Hb} / \mathrm{g}$ & 2007 & $50-74$ & 12 or 24 \\
\hline & & & Saskatchewan & Organised & Rollout complete & FIT & $20 \mu \mathrm{g} \mathrm{Hb} / \mathrm{g}$ & 2009 & $50-74$ & 24 \\
\hline & & & Manitoba & Organised & Rollout complete & gFOBT & $1 / 6$ slides & 2007 & $50-74$ & 24 \\
\hline & & & Quebec & Organised & $\begin{array}{l}\text { Pilot/planning } \\
\text { phase }\end{array}$ & FIT & & 2014 & $50-74$ & 24 \\
\hline & & & New Brunswick & Organised & $\begin{array}{l}\text { Pilot/planning } \\
\text { phase }\end{array}$ & FIT & & 2014 & & 24 \\
\hline & & & Nova Scotia & Organised & Rollout complete & FIT & $\begin{array}{l}1 / 2 \text { samples at } \\
300 \mu \mathrm{g} \mathrm{Hb} / \mathrm{g}\end{array}$ & 2009 & $50-74$ & 24 \\
\hline & & & Prince Edward Island & Organised & Rollout complete & FIT & & 2009 & $50-74$ & 24 \\
\hline & & & $\begin{array}{l}\text { Newfoundland and } \\
\text { Labrador }\end{array}$ & Organised & Rollout ongoing & FIT & & 2012 & $50-74$ & 24 \\
\hline & & & Yukon & No screening & & & & & & \\
\hline & & & Northwest territories & No screening & & & & & & \\
\hline & & & Nunavut & No screening & & & & & & \\
\hline Chile & 15 & 8.6 & Seven cities & Organised & Pilot & FIT & $20 \mu \mathrm{g} \mathrm{Hb} / \mathrm{g}$ & & & \\
\hline Cuba & 19.7 & 11.6 & & Opportunistic & & FIT & & & & \\
\hline Jamaica & 14.4 & 7.9 & & Opportunistic & & OC & & & & \\
\hline Martinique & 23.9 & 9.4 & & Organised & Rollout complete & FIT & $30 \mu \mathrm{g} \mathrm{Hb} / \mathrm{g}$ & 2007 & $50-74$ & 24 \\
\hline Mexico & 7.8 & 4.1 & & Opportunistic & & $\begin{array}{l}\text { gFOBT/ } \\
\text { FIT }\end{array}$ & & & $50+$ & \\
\hline Puerto Rico & 24.6 & 9.6 & & Opportunistic & & gFOBT/FS & & & $50-75$ & \\
\hline Trinidad/Tobago & 23.5 & 13.1 & & Opportunistic & & $\mathrm{gFOBT} / \mathrm{FI}$ & $10 C$ & & & \\
\hline Uruguay & 29.5 & 15.7 & & Opportunistic & & FIT & $20 \mu \mathrm{g} \mathrm{Hb} / \mathrm{g}$ & 1997 & $50+$ & 24 \\
\hline \multirow[t]{3}{*}{ USA } & 25 & 9.2 & & & & & & & & \\
\hline & & & $\begin{array}{l}\text { Kaiser Permanente North } \\
\text { Carolina }\end{array}$ & Organised & & $\mathrm{FIT} / \mathrm{OC}$ & & & $50-75$ & 12 \\
\hline & & & $\begin{array}{l}\text { Veterans Health } \\
\text { Administration }\end{array}$ & Organised & & gFOBT/FS & & & $51-75$ & \\
\hline \multicolumn{11}{|c|}{ Western Pacific. South-East Asia and Eastern Mediterranean region } \\
\hline Armenia & 19.3 & 11.1 & & Unknown & & & & & & \\
\hline Australia & 38 & 9 & All & Organised & Rollout ongoing & FIT & & & $50-74$ & 60 \\
\hline Brunei & 25 & 12 & & Opportunistic & & OC & & & & \\
\hline \multirow[t]{3}{*}{ China } & 14.2 & 7.4 & & & & & & & & \\
\hline & & & Hong Kong & Organised & Pilot & gFOBT/OC & & 2003 & $50+$ & \\
\hline & & & $\begin{array}{l}\text { Several including Shanghai } \\
\text { and Hangzhou regions }\end{array}$ & Organised & & gFOBT/DF & $\mathrm{E}+\mathrm{OC}$ & 2008 & $40-74$ & \\
\hline Israel & 35.9 & 11.1 & All & Organised & Rollout complete & FIT & & 1990 & $50-74$ & 12 \\
\hline Japan & 32.2 & 11.9 & All & Organised & Rollout complete & FIT & & 1992 & $40-69$ & 12 \\
\hline Jordan & 25.6 & 15.5 & & Opportunistic & & $\mathrm{gFOBT} / \mathrm{FI}$ & IOC & & $50+$ & \\
\hline Kazakhstan & 22.8 & 12.8 & & Unknown & & & & & & \\
\hline Korea, North & 21.8 & 10.7 & & Unknown & & & & & & \\
\hline Korea, South & 45 & 12 & All & Organised & & FIT & & 2004 & $50+$ & 12 \\
\hline Malaysia & 18.3 & 9.4 & & No organised s & reening & & & & & \\
\hline New Zealand & 37 & 15 & Waitemata & Organised & Pilot & FIT & $15 \mu \mathrm{g} \mathrm{Hb} / \mathrm{g}$ & 2011 & $50-74$ & \\
\hline Singapore & 33.7 & 11.8 & All & Organised & & FIT & & & $50+$ & 12 \\
\hline Taiwan & & & All & Organised & Rollout ongoing & FIT & & 2004 & $50-74$ & \\
\hline Thailand & 12.4 & 7.3 & Lampang Province & Organised & Pilot & FIT & $200 \mathrm{ng} / \mathrm{mL}$ & 2011 & $50-65$ & \\
\hline
\end{tabular}

${ }^{*}$ Weak positives (one to four of six slides positive) are retested.

tWeak positives (one to four of six slides positive) are retested with FIT.

ASRi, age-standardised incidence rates; ASRm, age-standardised mortality rates; DRE, digital rectal exam; FIT, faecal immunochemical test for haemoglobin; FS, flexible sigmoidoscopy; gFOBT, guaiac faecal occult blood test; OC, (optical) colonoscopy.

To match the number of FIT-positives with the available colonoscopy capacity, the FIT cut-off had to be raised in the Netherlands, Scotland and the Republic of Ireland. ${ }^{95} 96$
Compliance to colonoscopy following a positive non-invasive screening test can also be an issue. In Lithuania only $52.4 \%$ of the FIT-positives undergo colonoscopy; resulting in a very low 
combined adenoma and CRC detection rate of $1.2 \%$ cumulatively over 3 years. ${ }^{97}$

\section{Region of the Americas \\ North-America}

The ASRi for North America is 26.1 per 100000 (23 and 30 for women and men, respectively). ${ }^{1}$ An approximate 136830 persons have been diagnosed with CRC and 50310 persons died of the disease in the USA in $2014 .{ }^{98}$ An additional estimated 24400 new cases of CRC were diagnosed in Canada in the same year. ${ }^{99}$ Reimbursement for colonoscopy in these Western countries has facilitated the early adoption of opportunistic screening. For example, previous work in Ontario, Canada demonstrated an increase in colonoscopy use prior to the launch of an organised CRC screening programme in the province in $2008 .{ }^{100}$

To date, all 10 Canadian provinces have announced, are planning or have implemented organised CRC screening programmes. ${ }^{101}$ No organised screening programmes have been announced in any of the three territories. Special challenges faced by the territories include a lack of resources/facilities and a low population density across vast areas of land. Most provinces are currently using FIT to screen persons aged 5074 years at average risk for CRC (figure 1B). ${ }^{101}$ Ontario's ColonCancerCheck, Canada's first organised CRC screening programme, launched province-wide in 2008. ${ }^{102}$ Participation in the gFOBT aspect of the programme was $29.8 \%$ in 2010 $2011 .^{102}$ In Ontario in $2013,58 \%$ of the target population were up-to-date with CRC screening, taking all screening modalities into account. Early aggregate results from the first round of screening (January 2009-December 2011) of five other provincial programmes (British Columbia, Saskatchewan, Manitoba, Nova Scotia and Prince Edward Island) showed a much lower participation rate $(16.1 \%) .{ }^{103}$ Opportunistic screening colonoscopy is available to a variable extent in most Canadian provinces.

Colorectal cancer screening in the USA is recommended by the USPSTF for persons at average risk (50-75 years old) with annual gFOBT, periodic FS or colonoscopy. ${ }^{58}$ Data from the annual Behavioural Risk Factor Surveillance System survey revealed that approximately $65 \%$ of US adults were up-to-date with CRC screening in 2012, with colonoscopy being the most widely used test. ${ }^{104}$ The American Cancer Society recently reported that CRC incidence and mortality rates significantly decreased over the past decade. ${ }^{105}$ This is in particular attributed to CRC screening. ${ }^{106}$ Enablers for the success of opportunistic screening seen in USA include the quality initiative supported by national GI societies including USPSTF, American Cancer Society, American Gastroenterological Association, American Society for Gastrointestinal Endoscopy and National Colorectal Cancer Roundtable, among others. This has played a significant role in the high uptake of screening in the country. On the other hand, organised screening programmes in various regions of the country have also been established. Two prime examples include the Kaiser Permanente Northern California programme and the Veterans Health Administration programme. Kaiser Permanente Northern California programme participation rates have doubled since 2004 and were $69 \%$ in $2010^{107}$ while screening rates in the Veterans Health Administration programme among veterans aged 52 years or older were already as high as $68 \%$ as early as $2001 .{ }^{108}$

Mexico has also launched a CRC awareness campaign focusing on gFOBT screening but without much uptake.
Central and South America

Although numerous Central and South American countries have national guidelines in place for CRC screening, very few national screening programmes have been implemented. ${ }^{109} 110$ The current infrastructure in many countries is lacking to support a full organised screening programme. In addition, very little is done to raise awareness in most regions including Venezuela, Bolivia, Peru, Columbia and Costa Rica. As a result, many of those diagnosed with CRC in these regions are identified after the disease has metastasised. ${ }^{109}$

For example, in Brazil, screening colonoscopies for those aged 50 years and older have been approved by the Ministry of Health, but uptake remains low. ${ }^{109}$ Numerous CRC pilot programmes have begun in various municipalities. One example is the programme by the Brazilian Association for Colorectal Cancer Prevention, developed in Sao Paulo. ${ }^{111}$ Starting in 2006, those 40 years and older at average risk were screened with FIT. Of the 4567 kits that were distributed between August 2006 and March 2007, 79.7\% were returned and analysed. Positivity rates were approximately $10.7 \% .^{112}$

Some success was seen with Argentina's CRC screening programme in urban areas of the country. ${ }^{113}$ The programme will next be piloted in rural regions of the country. ${ }^{109}$ In Uruguay, a CRC pilot programme was launched in 1996 for those at average risk. Persons aged 50 years or older were screened with FIT and followed up with colonoscopy. ${ }^{72}$ Between June 1997 and July 2004, 90.1\% of the 11734 persons enrolled in the CRC screening programme completed a FIT. Of these, $11.1 \%$ had a positive test.

\section{Caribbean}

Organised screening for CRC is not routinely performed in the Caribbean. Opportunistic screening with colonoscopy is available on some islands. ${ }^{110}$ However, even with effective screening, many Caribbean countries lack the medical facilities to provide appropriate cancer treatment. As such, organised CRC screening is not a priority. For example, in Jamaica, screening accounts for $11 \%$ of the performed colonoscopies. ${ }^{114}$ Similarly, low uptake of CRC screening has been reported in other countries such as Puerto Rico and Cuba. ${ }^{115} 116$

\section{African region}

A mathematical modelling study showed that in the sub-Saharan African region, screening for CRC by colonoscopy at age 50 years in combination with treatment can be considered costeffective. $^{83}$ However, the need for population-based CRC screening in the low-income countries of Africa is questioned given the overall relatively low burden of disease, the substantial burden of communicable diseases and the limited resources. ${ }^{85}$ In addition, means by which to identify the target population, availability of colonoscopy and an appropriate number of well trained specialists are lacking in most regions. ${ }^{117}$

\section{Eastern Mediterranean region}

Predictions specific to the Eastern Mediterranean region indicate that generally countries in this part of the world will experience an increase in all cancer mortality of approximately $181 \%$ over the next 15 years. ${ }^{118}$ The current CRC incidence is highest in Israel (36 per 100 000), Jordan (26 per 100 000), Kazakhstan (23 per 100000$)$, Armenia (19 per 100000$)$, Syrian Arab Republic (16 per 100000$)$, Lebanon (16 per 100000$)$ and the State of Palestine (15 per 100000$)$. CRC mortality rates are highest in Jordan (16 per 100000$)$, Kazakhstan (13 per 
100 000), Armenia (11 per 100000$)$ and Israel (11 per $100000){ }^{1}$

In Israel, an organised programme for individuals aged 50-74 years has been put in place by the country's four healthcare providers with the government establishing national oversight of provider activities and quality. Insured persons are approached by their general practitioner for annual FIT screening. In Jordan, the national health authorities have not yet adopted a specific strategy or guidelines for CRC screening despite the high prevalence of the disease in the country. ${ }^{119}$ In Middle Eastern countries that have adopted a Western lifestyle, some opportunistic programmes are in place. Physicians in the United Arabic Emirates have called for countrywide screening but Abu Dhabi is the only emirate to screen for CRC. The Health Authority Abu Dhabi advises colonoscopy for people over the age of 40 years. ${ }^{120}$ An opportunistic FIT-based pilot study in Qatar showed a low colonoscopy follow-up rate among those with a positive FIT of $56 \% .^{121}$

\section{Western Pacific and South-East Asia region}

In the Asia Pacific region, CRC incidence varies among regions. The country with the highest CRC incidence in the world is Korea (ASRi 45 per 100 000). Other countries with high CRC incidence in Asia are Singapore (ASRi 34 per 100000 ) and Japan (ASRi 32 per 100000$).{ }^{1}$ There is an alarming rising trend in CRC incidence and mortality in Asia, especially in Japan, Korea and China. ${ }^{13}$ This trend has been explained by changes in diet and a westernised lifestyle. ${ }^{122}$ In addition, the overall prevalence of advanced colorectal neoplasia in asymptomatic Asian populations is similar to Western populations. ${ }^{123}$ The CRC incidence and mortality rates in India (6 per 100000 and 5 per 100000 , respectively) remain low compared with rising rates in East Asia. ${ }^{1} 124$

Recommendations for CRC screening in the Asia Pacific region have been published ${ }^{125}$ and recently updated. ${ }^{13}$ The Asia Pacific Colorectal Cancer Working Group recommends CRC screening in regions where the incidence is high, defined as greater than 30 per $100000 .{ }^{13}$ Recommendations include screening for those 50-75 years at average risk with a quantitative FIT as the preferred screening method. ${ }^{13}$ Those with a positive test result should be referred for colonoscopy. The guidelines recommend that a clinical risk index can be employed in regions with limited healthcare resources to prioritise screening in those at increased risk. Several studies investigated barriers to CRC screening in different cultural and sociopolitical contexts in the Asia Pacific region. These barriers included poor knowledge of CRC screening and test characteristics, lack of financial support and lack of health insurance. ${ }^{126-128}$

Several countries in the Asia Pacific region have already developed population-based screening programmes. This includes China, Japan, Taiwan, Korea and Singapore. In China, those aged 40-74 years are screened with gFOBT and followed up by a digital rectal exam and colonoscopy. However, the programme is not available to the entire population and the national registry used to track clinical outcomes is estimated to capture only $13 \%$ of the country's population, making planning for healthcare services difficult. ${ }^{129}$ Studies have shown that screening uptake in China is low and varies widely. ${ }^{129}{ }^{130}$ In Japan, a CRC screening programme has been in place since 1992 for national health insurance beneficiaries. ${ }^{67}$ Individuals aged $40-69$ years with national health insurance are offered screening with FIT. In 2010, participation rates for those aged 40-69 years were $28.1 \%$ for men and $23.9 \%$ for women. ${ }^{131}$ Nationwide CRC screening was introduced in the Republic of Korea in 2004. The National
Cancer Screening Program sends invitation letters to the target population at the beginning of the year advising them to get screened with annual FIT, while those with a positive test are offered follow-up with colonoscopy or double contrast barium enema. ${ }^{63}{ }^{69}$ Published results from the programme show an increase in participation rates since launch $(10.5 \%$ in 2004 to $21.1 \%$ in 2008 ) and a decline in positivity rates from $8.0 \%$ to $6.8 \% .{ }^{63}$ Opportunistic screening is also available in the region.

In other regions, such as Hong Kong, community-based screening programmes have been piloted to evaluate the feasibility of a large population-based organised screening programme. Similarly in New Zealand, a 4-year CRC screening pilot began in late 2011 to determine whether a screening programme should be rolled out nationally. The pilot results will inform the decision regarding implementation of a national populationbased screening programme. In Thailand, an organised pilot programme based on FIT screening has been implemented in April 2011. It focuses on persons aged 50-65 years in the Lampang Province. ${ }^{65}$ Preliminary results from the pilot show participation rates of $62.9 \%$ among the 127301 persons in the target population. ${ }^{65}$

In Australia, a pilot started in 2002. In 2006, the National Bowel Cancer Screening Program began providing biennial FIT (New Hem Tube) to people turning 55 years and 65 years. The programme will continue to expand between 2015 and 2020 to fully implement biennial screening for all Australians aged 50 74 years. ${ }^{132}$ In other regions, such as in Malaysia, no organised population-based screening programme exists despite published guidelines for CRC screening. ${ }^{133}$

\section{CONCLUSION}

CRC incidence and mortality rates vary widely among continents and within continents. High-quality incidence and mortality data allow understanding of disease and are thus the first essential step for effective cancer control planning. In considering whether to move forward with a CRC screening programme, the local impact of the disease relative to other health problems and the capacity to treat the disease adequately should be taken into account. Non-communicable diseases as CRC are rapidly becoming the leading healthcare problem in middle-income and low-income countries. This in particular pertains to those countries that are transitioning to Western lifestyles and have aging populations. Therefore, the need to consider implementing CRC screening beyond the countries in which it is currently taking place is likely to increase over time. Most countries with a high CRC incidence however, already have some form of screening in place.

Despite major changes over the past 15 years, there remain many countries without population-based CRC screening despite high CRC incidence and mortality. This is in most cases explained by limitations in resources including colonoscopy capacity, and the organisation of structure of healthcare delivery. Some countries without an existing programme already have CRC screening on the agenda. This will likely result in implementation of CRC screening in the coming years.

Most organised CRC screening programmes use non-invasive stool tests (FIT or gFOBT), whereas most opportunistic programmes are based on endoscopy, in particular colonoscopy. For both screening strategies, levels of screening uptake vary considerably throughout the world. A screening strategy should be chosen carefully to meet the needs of the applicable screening scenario. A comprehensive understanding of the full range of screening modalities and strategies available for CRC screening 
is needed for appropriate selection of strategies relative to available financial resources and colonoscopy capacity.

The lack of CRC screening in many countries and the low screening uptake in various others provide room for improvement. In countries with a CRC screening programme with low uptake levels, targeted actions need to be considered to improve uptake. This may include adaptations to the invitation and follow-up protocol, in particular implementing an active call-recall system. Other measures may include a change to or addition of another screening modality. Professional gastroenterology associations may actively promote such changes in close conjunction with health authorities and screening organisations.

Finally, quality assurance and evaluation is of paramount importance to ensure optimal impact, minimal burden and balanced use of resources. Therefore, screening measures and quality indicators should be reported, allowing national evaluation and international comparison to improve CRC screening quality.

In conclusion, the global challenge is to evaluate the need for CRC screening in a given jurisdiction or country, and, if indicated, to develop a tailored CRC screening programme for which the uptake is high. This is especially necessary for low resource countries that face an increase in CRC incidence, as populations adopt a more Westernised lifestyle.

\author{
Author affiliations \\ ${ }^{1}$ Department of Gastroenterology and Hepatology, Erasmus MC, University Medical \\ Centre, Rotterdam, The Netherlands \\ ${ }^{2}$ Sunnybrook Research Institute, Sunnybrook Health Sciences Centre, Toronto, \\ Ontario, Canada \\ ${ }^{3}$ Institute for Clinical Evaluative Sciences, Toronto, Ontario, Canada \\ ${ }^{4}$ Prevention and Cancer Control, Cancer Care Ontario, Toronto, Ontario, Canada \\ ${ }^{5}$ Department of Medicine, University of Toronto, Toronto, Ontario, Canada \\ ${ }^{6}$ Institute of Health Policy, Management and Evaluation, University of Toronto, \\ Toronto, Ontario, Canada \\ ${ }^{7}$ Dalla Lana School of Public Health, University of Toronto, Toronto, Ontario, Canada \\ ${ }^{8}$ Division of Gastroenterology, Hepatology and Nutrition, University of Pittsburgh, \\ Pittsburgh, Pennsylvania, USA \\ ${ }^{9}$ Institute of Digestive Disease, Chinese University of Hong Kong, Hong Kong, Hong \\ Kong \\ ${ }^{10}$ Flinders Centre for Innovation in Cancer, Flinders University, Adelaide, South \\ Australia, Australia
}

Contributors EJK designed and conceptualised the outline of the paper. The manuscript was drafted by EHS and AR. All coauthors provided critical revision for important intellectual content.

Competing interests We have read and understood BMJ policy on declaration of interests and declare the following interests: no support from any organisation for the submitted work; no financial relationships with any organisations that might have an interest in the submitted work in the previous 3 years; no other relationships or activities that could appear to have influenced the submitted work. GPY chairs the Scientific Advisory Board for Clinical genomics but none of their products are referred to in this manuscript.

Provenance and peer review Commissioned; externally peer reviewed.

\section{REFERENCES}

1 GLOBOCAN. Estimated cancer incidence, mortality and prevalence worldwide in 2012. 2012. http://globocan.iarc.fr/Default.aspx

2 Forman D, Bray F, Brewster DH, et al. Cancer incidence in five continents. Vol X. International Agency for Research on Cancer, 2014.

3 Ferlay J, Shin HR, Bray F, et al. Estimates of worldwide burden of cancer in 2008: GLOBOCAN 2008. Int I Cancer 2010;127:2893-917.

4 Lansdorp-Vogelaar I, van Ballegooijen M, Zauber AG, et al. Effect of rising chemotherapy costs on the cost savings of colorectal cancer screening. I Natl Cancer Inst 2009:101:1412-22.

5 Kuntz KM, Lansdorp-Vogelaar I, Rutter CM, et al. A systematic comparison of microsimulation models of colorectal cancer: the role of assumptions about adenoma progression. Med Decis Making 2011;31:530-9.

6 Brenner $\mathrm{H}$, Hoffmeister M, Stegmaier $\mathrm{C}$, et al. Risk of progression of advanced adenomas to colorectal cancer by age and sex: estimates based on 840,149 screening colonoscopies. Gut 2007;56:1585-9.
7 Winawer SJ, Zauber AG, Ho MN, et al. Prevention of colorectal cancer by colonoscopic polypectomy. The National Polyp Study Workgroup. N Engl I Med 1993;329:1977-81.

8 Stryker SJ, Wolff BG, Culp CE, et al. Natural history of untreated colonic polyps. Gastroenterology 1987;93:1009-13.

9 Wilson JM, Jungner YG. [Principles and practice of mass screening for disease]. Boletin de la Oficina Sanitaria Panamericana Pan American Sanitary Bureau 1968:65:281-393.

10 The Canadian Task Force on Preventive Health Care. Colorectal cancer screening: Recommendation statement from the Canadian Task Force on Preventive Health Care. Can Med Assoc J 2001;165:206-8.

11 Levin B, Lieberman DA, McFarland B, et al. Screening and surveillance for the early detection of colorectal cancer and adenomatous polyps, 2008: a joint guideline from the American Cancer Society, the US Multi-Society Task Force on Colorectal Cancer, and the American College of Radiology. CA Cancer I Clin 2008:58:130-60.

12 von Karsa L, Patnick J, Segnan N. European guidelines for quality assurance in colorectal cancer screening and diagnosis. First Edition-Executive summary. Endoscopy 2012:44(Suppl 3):SE1-8.

13 Sung JJ, Ng SC, Chan FK, et al. An updated Asia Pacific Consensus Recommendations on colorectal cancer screening. Gut 2015;64:121-32.

14 World Endoscopy Organization. WEO Colorectal Cancer Screening Committee. WEO/OMED, 2015.

15 Benson VS, Atkin WS, Green J, et al. Toward standardizing and reporting colorectal cancer screening indicators on an international level: the International Colorectal Cancer Screening Network. Int I Cancer 2012;130: 2961-73.

16 International Agency for Research on Cancer. Handbook of cancer prevention: cervix cancer screening. Lyon: IARC Press, 2010.

17 Fraser CG, Allison JE, Young GP, et al. Improving the reporting of evaluations of faecal immunochemical tests for haemoglobin: the FITTER standard and checklist. Eur J Cancer Prev 2015;24:24-6.

18 Fraser CG, Allison JE, Halloran SP, et al. A Proposal to Standardize Reporting Units for Fecal Immunochemical Tests for Hemoglobin. J Natl Cancer Inst 2012;104:810-14.

19 Hewitson P, Glasziou P, Watson E, et al. Cochrane systematic review of colorectal cancer screening using the fecal occult blood test (hemoccult): an update. Am J Gastroenterol 2008;103:1541-9.

20 Brenner $\mathrm{H}$, Hoffmeister M, Birkner B, et al. Diagnostic performance of guaiac-based fecal occult blood test in routine screening: state-wide analysis from Bavaria, Germany. Am J Gastroenterol 2014;109:427-35.

21 Hol L, van Leerdam ME, van Ballegooijen M, et al. Screening for colorectal cancer: randomised trial comparing guaiac-based and immunochemical faecal occult blood testing and flexible sigmoidoscopy. Gut 2010;59:62-8.

22 van Rossum $L G$, van Rijn AF, Laheij RJ, et al. Random comparison of guaiac and immunochemical fecal occult blood tests for colorectal cancer in a screening population. Gastroenterology 2008;135:82-90.

23 Wilschut JA, Hol L, Dekker E, et al. Cost-effectiveness analysis of a quantitative immunochemical test for colorectal cancer screening. Gastroenterology 2011;141:1648-55.e1.

24 Hol L, Wilschut JA, van Ballegooijen M, et al. Screening for colorectal cancer: random comparison of guaiac and immunochemical faecal occult blood testing at different cut-off levels. Br J Cancer 2009;100:1103-10.

25 Zorzi M, Fedeli U, Schievano E, et al. Impact on colorectal cancer mortality of screening programmes based on the faecal immunochemical test. Gut 2015;64:784-90.

26 Zauber AG, Lansdorp-Vogelaar I, Knudsen AB, et al. Evaluating Test Strategies for Colorectal Cancer Screening - Age to Begin, Age to Stop, and Timing of Screening Intervals: a Decision Analysis of Colorectal Cancer Screening for the U.S. PreventiveServices Task Force from the Cancer Intervention and Surveillance Modeling Network (CISNET). Rockville, MD: Agency for Healthcare Research and Quality (US), 2009.

27 Atkin WS, Edwards R, Kralj-Hans I, et al. Once-only flexible sigmoidoscopy screening in prevention of colorectal cancer: a multicentre randomised controlled trial. Lancet 2010;375:1624-33.

28 Schoen RE, Pinsky PF, Weissfeld JL, et al. Colorectal-cancer incidence and mortality with screening flexible sigmoidoscopy. N Engl J Med 2012;366:2345-57.

29 Segnan N, Armaroli P, Bonelli L, et al. Once-only sigmoidoscopy in colorectal cancer screening: follow-up findings of the Italian Randomized Controlled TrialSCORE. J Natl Cancer Inst 2011;103:1310-22.

30 Holme $\mathrm{O}$, Loberg $\mathrm{M}$, Kalager $\mathrm{M}$, et al. Effect of flexible sigmoidoscopy screening on colorectal cancer incidence and mortality: a randomized clinical trial. JAMA 2014;312:606-15.

31 Kaminski MF, Bretthauer M, Zauber AG, et al. The NordICC Study: rationale and design of a randomized trial on colonoscopy screening for colorectal cancer. Endoscopy 2012;44:695-702.

32 Quintero E, Castells A, Bujanda L, et al. Colonoscopy versus fecal immunochemical testing in colorectal-cancer screening. N Engl J Med 2012;366:697-706. 
33 Zauber AG, Winawer SJ, O'Brien MJ, et al. Colonoscopic polypectomy and longterm prevention of colorectal-cancer deaths. N Engl J Med 2012;366:687-96.

34 Nishihara R, Wu K, Lochhead P, et al. Long-term colorectal-cancer incidence and mortality after lower endoscopy. N Engl J Med 2013;369:1095-105.

35 de Haan MC, van Gelder RE, Graser A, et al. Diagnostic value of CT-colonography as compared to colonoscopy in an asymptomatic screening population: a meta-analysis. Eur Radiol 2011;21:1747-63.

36 Pickhardt PJ, Choi JR, Hwang I, et al. Computed tomographic virtual colonoscopy to screen for colorectal neoplasia in asymptomatic adults. N Engl J Med 2003;349:2191-200.

37 Pickhardt PJ, Hassan C, Halligan S, et al. Colorectal cancer: CT colonography and colonoscopy for detection-systematic review and meta-analysis. Radiology 2011;259:393-405.

38 Whitlock EP, Lin JS, Liles E, et al. Screening for colorectal cancer: a targeted, updated systematic review for the U.S. Preventive Services Task Force. Ann Intern Med 2008;149:638-58.

39 Church TR, Wandell M, Lofton-Day C, et al. Prospective evaluation of methylated SEPT9 in plasma for detection of asymptomatic colorectal cancer. Gut 2014;63:317-25.

40 Imperiale TF, Ransohoff DF, Itzkowitz SH, et al. Multitarget stool DNA testing for colorectal-cancer screening. N Engl J Med 2014;370:1287-97.

41 Spada C, Hassan C, Barbaro B, et al. Colon capsule versus CT colonography in patients with incomplete colonoscopy: a prospective, comparative trial. Gut 2015;64:272-81.

42 Graser A, Melzer A, Lindner E, et al. Magnetic resonance colonography for the detection of colorectal neoplasia in asymptomatic adults. Gastroenterology 2013;144:743-50.e2.

43 Graser A, Stieber P, Nagel D, et al. Comparison of CT colonography, colonoscopy, sigmoidoscopy and faecal occult blood tests for the detection of advanced adenoma in an average risk population. Gut 2009;58:241-8.

44 Brenner $\mathrm{H}$, Tao S. Superior diagnostic performance of faecal immunochemical tests for haemoglobin in a head-to-head comparison with guaiac based faecal occult blood test among 2235 participants of screening colonoscopy. Eur J Cancer 2013;49:3049-54

45 Imperiale TF, Ransohoff DF, Itzkowitz SH, et al. Fecal DNA versus fecal occult blood for colorectal-cancer screening in an average-risk population. N Engl J Med 2004;351:2704-14.

46 Lieberman DA, Weiss DG, Veterans Affairs Cooperative Study G. One-time screening for colorectal cancer with combined fecal occult-blood testing and examination of the distal colon. N Engl J Med 2001;345:555-60.

47 Park DI, Ryu S, Kim YH, et al. Comparison of guaiac-based and quantitative immunochemical fecal occult blood testing in a population at average risk undergoing colorectal cancer screening. Am J Gastroenterol 2010;105:2017-25.

48 Ahlquist DA, Sargent DJ, Loprinzi CL, et al. Stool DNA and occult blood testing for screen detection of colorectal neoplasia. Ann Intern Med 2008;149:441-50.

49 Chiu H, Lee $Y$, Tu C, et al. Association between early stage colon neoplasms and false-negative results from the fecal immunochemical test. Clin Gastroenterol Hepatol 2013:11:832-8.

50 Zauber AG, Lansdorp-Vogelaar I, Knudsen AB, et al. Evaluating Test Strategies for Colorectal Cancer Screening: A Decision Analysis for the U.S. Preventive Services Task Force. Ann Intern Med 2008;149:659-69.

51 Lieberman DA. Clinical practice. Screening for colorectal cancer. N Engl J Med 2009;361:1179-87.

52 Lee JK, Liles EG, Bent $\mathrm{S}$, et al. Accuracy of fecal immunochemical tests for colorectal cancer: systematic review and meta-analysis. Ann Intern Med 2014; $160: 171$.

53 de Haan MC, Pickhardt PJ, Stoker J. CT colonography: accuracy, acceptance, safety and position in organised population screening. Gut 2015;64:342-50.

54 Holme 0, Bretthauer M, Fretheim A, et al. Flexible sigmoidoscopy versus faecal occult blood testing for colorectal cancer screening in asymptomatic individuals. Cochrane Database Syst Rev 2013;9:CD009259.

55 Brenner H, Stock C, Hoffmeister M. Effect of screening sigmoidoscopy and screening colonoscopy on colorectal cancer incidence and mortality: systematic review and meta-analysis of randomised controlled trials and observational studies. BMJ 2014;348:g2467.

56 Kuipers EJ, Rosch T, Bretthauer M. Colorectal cancer screening-optimizing current strategies and new directions. Nat Rev Clin Oncol 2013;10:130-42.

57 Miles A, Cockburn J, Smith RA, et al. A perspective from countries using organized screening programs. Cancer 2004;101:1201-13.

58 U.S. Preventive Services Task Force. Screening for colorectal cancer: U.S. Preventive Services Task Force recommendation statement. Ann Intern Med 2008;149:627-37

59 Rex DK, Johnson DA, Anderson JC, et al. American College of Gastroenterology guidelines for colorectal cancer screening 2009 [corrected]. Am J Gastroenterol 2009;104:739-50.

60 Gupta S, Sussman DA, Doubeni CA, et al. Challenges and Possible Solutions to Colorectal Cancer Screening for the Underserved. J Natl Cancer Inst 2014;106: dju032. doi:10.1093/jnci/dju032. Epub 2014 Mar 28.
61 Moss $S$, Ancelle-Park R, Brenner $H$. European guidelines for quality assurance in colorectal cancer screening and diagnosis. First Edition-Evaluation and interpretation of screening outcomes. Endoscopy 2012;44:25.

62 Karsa LV, Lignini TA, Patnick J, et al. The dimensions of the CRC problem. Best Pract Res Clin Gastroenterol 2010;24:381-96.

63 Choi KS, Lee HY, Jun JK, et al. Adherence to follow-up after a positive fecal occult blood test in an organized colorectal cancer screening program in Korea, 2004-2008. J Gastroenterol Hepatol 2012;27:1070-7.

64 Levi Z, Birkenfeld S, Vilkin A, et al. A higher detection rate for colorectal cancer and advanced adenomatous polyp for screening with immunochemical fecal occult blood test than guaiac fecal occult blood test, despite lower compliance rate. A prospective, controlled, feasibility study. Int J Cancer 2011;128:2415-24.

65 Khuhaprema T, Sangrajrang S, Lalitwongsa S, et al. Organised colorectal cancer screening in Lampang Province, Thailand: preliminary results from a pilot implementation programme. BMJ Open 2014;4:e003671.

66 Lopez-Kostner F, Kronber U, Zarate AJ, et al. [A screening program for colorectal cancer in Chilean subjects aged fifty years or more]. Rev Med Chil 2012;140:281-6.

67 Saito $\mathrm{H}$. Colorectal cancer screening using immunochemical faecal occult blood testing in Japan. J Med Screen 2006;13:S6-7.

68 Segnan N, Senore C, Andreoni B, et al. Comparing attendance and detection rate of colonoscopy with sigmoidoscopy and FIT for colorectal cancer screening. Gastroenterology 2007;132:2304-12.

69 Shim Jl, Kim Y, Han MA, et al. Results of colorectal cancer screening of the national cancer screening program in Korea, 2008. Cancer Res Treat 2010;42:191-8.

70 Tepes B, Stabuc B, Stefanovic M, et al. Faecal immunochemical test-based colorectal cancer screening programme SVIT in Slovenia: pilot phase. Eur J Cancer Prev 2014;23:235-9

71 Yeoh KG, Chew L, Wang SC. Cancer screening in Singapore, with particular reference to breast, cervical and colorectal cancer screening. J Med Screen 2006:13:\$14-19.

72 Fenocchi E, Martinez L, Tolve J, et al. Screening for colorectal cancer in Uruguay with an immunochemical faecal occult blood test. Eur J Cancer Prev 2006;15:384-90.

73 Senore C, Ederle A, Benazzato L, et al. Offering people a choice for colorectal cancer screening. Gut 2013;62:735-40.

74 Atkin WS, Cook CF, Cuzick J, et al. Single flexible sigmoidoscopy screening to prevent colorectal cancer: baseline findings of a UK multicentre randomised trial. Lancet 2002;359:1291-300.

75 Weissfeld JL, Schoen RE, Pinsky PF, et al. Flexible sigmoidoscopy in the PLCO cancer screening trial: results from the baseline screening examination of a randomized trial. J Natl Cancer Inst 2005;97:989-97.

76 Scott RG, Edwards JT, Fritschi L, et al. Community-based screening by colonoscopy or computed tomographic colonography in asymptomatic average-risk subjects. Am J Gastroenterol 2004;99:1145-51.

77 Stoop EM, de Haan MC, de Wijkerslooth TR, et al. Participation and yield of colonoscopy versus non-cathartic CT colonography in population-based screening for colorectal cancer: a randomised controlled trial. Lancet Oncol 2012;13:55-64.

78 Lieberman DA, Weiss DG, Bond JH, et al. Use of Colonoscopy to Screen Asymptomatic Adults for Colorectal Cancer. N Engl J Med 2000;343:162-8.

79 Schoenfeld P, Cash B, Flood A, et al. Colonoscopic screening of average-risk women for colorectal neoplasia. N Engl J Med 2005;352:2061-8.

80 Vanness DJ, Knudsen AB, Lansdorp-Vogelaar I, et al. Comparative economic evaluation of data from the ACRIN National CT Colonography Trial with three cancer intervention and surveillance modeling network microsimulations. Radiology 2011:261:487-98.

81 Lansdorp-Vogelaar I, Knudsen AB, Brenner H. Cost-effectiveness of colorectal cancer screening. Epidemiol Rev 2011:33:88-100.

82 Pignone M, Saha S, Hoerger T, et al. Cost-effectiveness analyses of colorectal cancer screening: a systematic review for the U.S. Preventive Services Task Force. Ann Intern Med 2002;137:96-104.

83 Ginsberg GM, Lauer JA, Zelle $\mathrm{S}$, et al. Cost effectiveness of strategies to combat breast, cervical, and colorectal cancer in sub-Saharan Africa and South East Asia: mathematical modelling study. BMJ 2012;344:e614.

84 Ginsberg GM, Lim SS, Lauer JA, et al. Prevention, screening and treatment of colorectal cancer: a global and regional generalized cost effectiveness analysis Cost Eff Resour Alloc 2010;8:2.

85 Rabeneck L. Horton S, Zauber A, et al. Colorectal cancer. In: Gelband H, Horton $\mathrm{S}$, Jha $\mathrm{P}$, et al, eds. Disease control priorities in developing countries. Washington DC: World Bank, 2015:Forthcoming.

86 Ferlay J, Steliarova-Foucher E, Lortet-Tieulent J, et al. Cancer incidence and mortality patterns in Europe: estimates for 40 countries in 2012. Eur J Cancer 2013:49:1374-403.

87 Ministry of Health Slovak Republic. List of departments performing endoscopic screening for colorectal cancer (screening and primary screening colonoscopy) under the Professional Guidelines of the Ministry of Health no. Z06173 / 2011 -CFC for the execution of colorectal cancer screening, published in the Bulletin 
of the Ministry of Health, Volume 59, figure 19-31, dated September 1, 2011. 2001.

88 Sporea IP, Popescu A. No colorectal cancer screening program in Romania! Thus, start with opportunistic screening. Rev Med Chir Soc Med Nat lasi 2014;118:598-600.

89 Avksentyeva M. Colorectal cancer in Russia. Eur J Health Econ 2010;10(Suppl 1): S91-8.

90 Zavoral M, Suchanek S, Majek 0 , et al. Colorectal cancer screening: 20 years of development and recent progress. World I Gastroenterol 2014;20:3825-34

91 Haidinger G, Waldhoer T, Vutuc C. Self-reported colonoscopy screening in Austria. Eur J Cancer Prev 2008;17:354-7.

92 Leuraud K, Jezewski-Serra D, Viguier J, et al. Colorectal cancer screening by guaiac faecal occult blood test in France: Evaluation of the programme two years after launching. Cancer Epidemiol 2013;37:959-67.

93 Faivre J, Arveux P, Milan C, et al. Participation in mass screening for colorectal cancer: results of screening and rescreening from the Burgundy study. Eur I Cancer Prev 1991:1:49-55.

94 Katicic M, Antoljak N, Kujundzic M, et al. Results of National Colorectal Cancer Screening Program in Croatia (2007-2011). World I Gastroenterol 2012;18:4300-7.

95 Steele RJC, McDonald PJ, Digby J, et al. Clinical outcomes using a faecal immunochemical test for haemoglobin as a first-line test in a national programme constrained by colonoscopy capacity. United European Gastroenterology Journal 2013;1:198-205

96 van Veldhuizen H, Heijnen, M-L, Lansdorp-Vogelaar I. Adjustment to the implementation of the colorectal cancer screening programme in 2014 and 2015. 2014.

97 Poskus T, Strupas K, Mikalauskas S, et al. Initial results of the National Colorectal Cancer Screening Program in Lithuania. Eur I Cancer Prev 2015;24:76-80.

98 American Cancer Society CCAG. Cancer facts \& figures 2014. Atlanta, 2014.

99 Canadian Cancer Society. Canadian Cancer Statistics 2014. Toronto, ON, 2014.

100 Vinden C, Schultz S, Rabeneck L. ICES research atlas: use of large bowel procedures in Ontario. Institute for Clinical Evaluative Sciences, 2004.

101 Canadian Partnership Against Cancer. Colorectal cancer screening in Canada: Program performance results, January 2009-December 2011. Toronto 2013.

102 Rabeneck L, Tinmouth JM, Paszat LF, et al. Ontario's ColonCancerCheck: results from Canada's first province-wide colorectal cancer screening program. Cancer Epidemiol Biomark Prev 2014;23:508-15.

103 Major D, Bryant H, Delaney M, et al. Colorectal cancer screening in Canada: results from the first round of screening for five provincial programs. Curr Oncol 2013;20:252-7.

104 Centers for Disease Control and Prevention. Morbidity and mortality weekly report: Colorectal cancer screening test use-United States, 2012. 2013.

105 Siegel R, Desantis C, Jemal A. Colorectal cancer statistics, 2014. CA Cancer I Clin 2014;64:104-17.

106 Edwards BK, Ward E, Kohler BA, et al. Annual report to the nation on the status of cancer, 1975-2006, featuring colorectal cancer trends and impact of interventions (risk factors, screening, and treatment) to reduce future rates. Cancer 2010;116:544-73

107 Levin TR, Jamieson L, Burley DA, et al. Organized Colorectal Cancer Screening in Integrated Health Care Systems. Epidemiol Rev 2011;33:101-10.

$108 \mathrm{Chao} \mathrm{HH}$, Schwartz AR, Hersh J, et al. Improving colorectal cancer screening and care in the Veterans Affairs Healthcare system. Clin Colorectal Cancer 2009:8:22-8.

109 Latin American Expert Summit for Metastatic Colorectal Cancer. Improving outcomes in the treatment and management of metastatic colorectal cancer in Latin America. 2014.
110 Pan American Health Organization. Cancer in the Americas: Country Profiles 2013. WHO, 2013.

111 Coy C. Colorectal cancer prevention in Brazil-where are we? J Coloproctol 2013:33:111-12.

112 Perez RO, Proscurshim I, São Julião GP, et al. Instalação e resultados preliminares de programa de rastreamento populacional de câncer colorretal em município brasileiro. ABCD Arquivos Brasileiros de Cirurgia Digestiva (São Paulo) 2008;21:12-15

113 Instituto Nacional del Cancer. Programa nacional de prevencion y deteccion temprana del cancer colorrectal.

114 Plummer JM, Mitchell DI, Ferron-Boothe D, et al. Colonoscopy in central Jamaica: results and implications. West Indian Med I 2012:61:610-14.

115 Gonzalez RS. Cancer Screening: Global Debates and Cuban Experience. MEDICC Review 2014;16:73-7.

116 Lopez-Charneco M, Perez CM, Soto-Salgado M, et al. Correlates of colorectal cancer screening among Hispanics: Results from the 2008 Puerto Rico behavioral risk factor surveillance system survey. $P$ R Health Sci J 2013:32:68-75.

117 Lambert R, Sauvaget C, Sankaranarayanan R. Mass screening for colorectal cancer is not justified in most developing countries. Int I Cancer 2009:125:253-6.

118 Dey S, Soliman AS. Cancer in the global health era: opportunities for the Middle East and Asia. Asia Pac J Public Health 2010;22:75S-82S.

119 Omran S, Barakat H, Muliira JK, et al. Knowledge, experiences, and barriers to colorectal cancer screening: a survey of health care providers working in primary care settings. J Cancer Educ 2015;30:53-61.

120 Health Authority Abu Dhabi. Cancer screening recommendations. HAAD, 2015.

121 John A, Al Kaabi S, Dweik N, et al. Emerging role for colorectal cancer screening in Asian countries. Trop Gastroenterol 2014;35:21-4.

122 Sung JJ, Lau JY, Goh KL, et al. Increasing incidence of colorectal cancer in Asia: implications for screening. Lancet Oncol 2005;6:871-6.

123 Byeon JS, Yang SK, Kim TI, et al. Colorectal neoplasm in asymptomatic Asians: a prospective multinational multicenter colonoscopy survey. Gastrointest Endosc 2007:65:1015-22.

124 Pathy $S$, Lambert $R$, Sauvaget $C$, et al. The incidence and survival rates of colorectal cancer in India remain low compared with rising rates in East Asia. Dis Colon Rectum 2012:55:900-6.

125 Sung JJ, Lau JY, Young GP, et al. Asia Pacific consensus recommendations for colorectal cancer screening. Gut 2008;57:1166-76.

126 Cai SR, Zhang SZ, Zhu HH, et al. Barriers to colorectal cancer screening: a case-control study. World I Gastroenterol 2009;15:2531-6.

127 Sung JJ, Choi SY, Chan FK, et al. Obstacles to colorectal cancer screening in Chinese: a study based on the health belief model. Am I Gastroenterol 2008;103:974-81.

$128 \mathrm{Koo} \mathrm{JH}$, Leong RW, Ching J, et al. Knowledge of, attitudes toward, and barriers to participation of colorectal cancer screening tests in the Asia-Pacific region: a multicenter study. Gastrointest Endosc 2012;76:126-35.

129 Goss PE, Strasser-Weippl K, Lee-Bychkovsky BL, et al. Challenges to effective cancer control in China, India, and Russia. Lancet Oncol 2014;15: 489-538.

130 Kang LN, Qiao RL. Cancer screening and prevention in China. Cancer Control 2014;8:131-3

131 Center for Cancer Control and Information Services NCC. Cancer statistics in Japan '13. Japan: Foundation for Promotion of Cancer Research, 2013.

132 Australian Government. Health Portfolio Budget Statements. Budget Related Paper No. 1.10. Department outcomes. Outcome 1: Population health. 2014.

133 Malaysian Society of Gastroenterology \& Hepatology. Screening for colorectal cancer in Malaysia. Consensus/clinical practice guidelines. 2001. 